
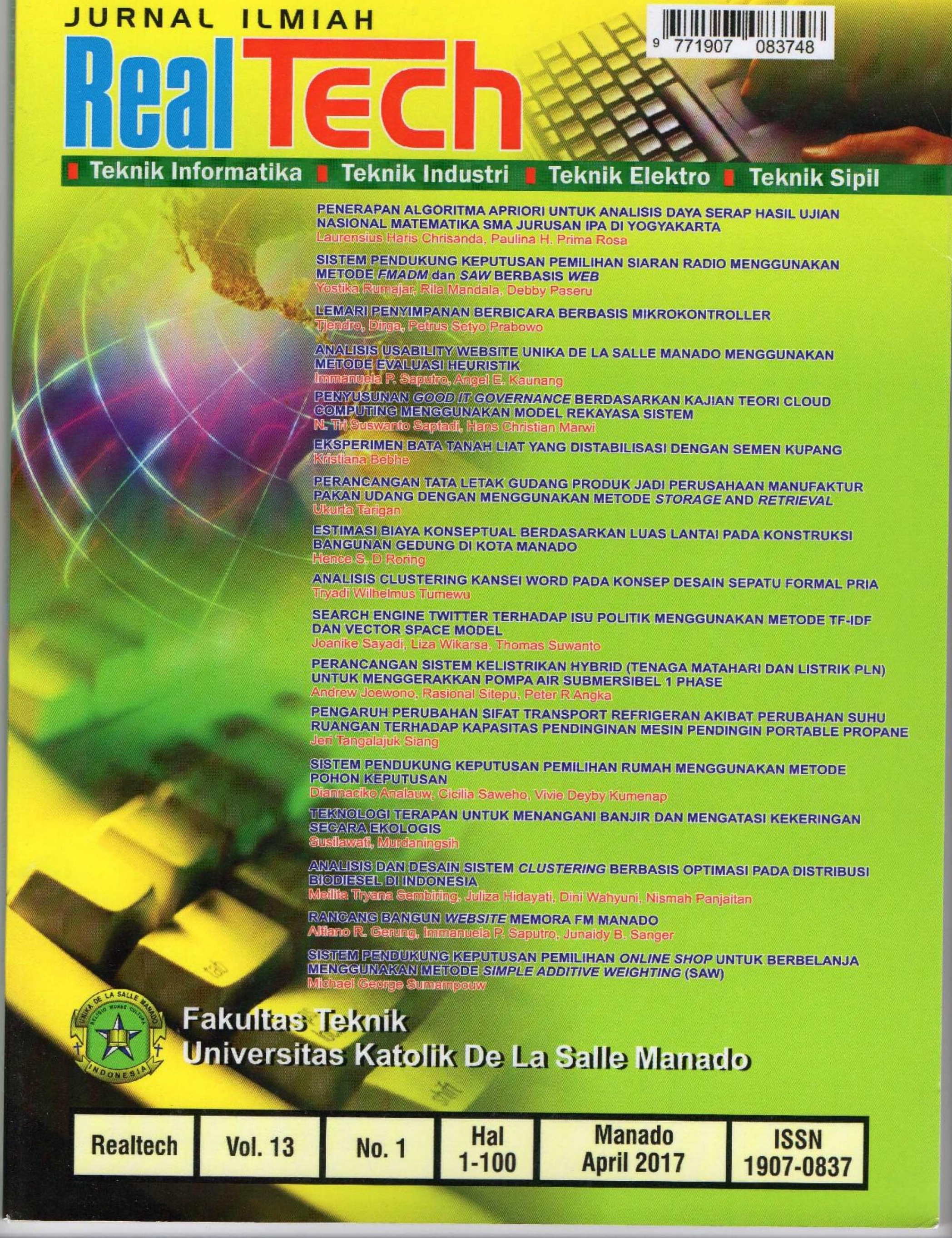


\title{
RANCANG BANGUN WEBSITE MEMORA FM MANADO
}

\author{
Altiano R. Gerung*1 ${ }^{*}$ Immanuela P. Saputro ${ }^{2}$, Junaidy B. Sanger ${ }^{3}$ \\ 1,2,3 Program Studi Teknik Informatika; Fakultas Teknik \\ 1,2,3 Universitas Katolik De La Salle Manado; Telp. (0431) 877512 \\ e-mail: *112013008@unikadelasalle.ac.id, ${ }^{2}$ isaputro@unikadelasalle.ac.id, ${ }^{3}$ jsanger@ unikadelasalle.ac.id
}

\begin{abstract}
Abstrak - Rancang bangun website dalam tulisan ini bertujuan untuk mengembangkan Website Memora FM Manado dengan beberapa fitur diantaranya: fitur audio streaming, penyedia informasi mengenai program yang dijalankan (on-air maupun offair), music chart, pemasangan iklan di website, lowongan pekerjaan, dan e-mail subscription. Pokok permasalahan hanya dibatasi pada bagaimana untuk merancang dan mengimplementasikan sistem. Metode yang digunakan untuk membangun sistem adalah Web Modeling Language. Hasil yang diperoleh dari penelitian ini setelah diuji coba menunjukkan bahwa sistem yang telah dibangun, dalam hal ini Website Memora FM Manado telah bekerja dengan baik dan sesuai dengan kebutuhan yakni: jangkauan program on-air menjadi lebih luas karena bisa didengar melalui website, memberikan informasi program off-air yang akan datang, memberikan music chart terkini versi Memora FM Manado, iklan yang disiarkan melalui siaran radio dapat juga dipromosikan melalui website, memberitahukan lowongan pekerjaan yang tersedia serta mempermudah para pendengar radio untuk mendapatkan informasi program on-air, off-air terbaru, dan program yang sedang open request melalui $e$-mail.
\end{abstract}

Kata Kunci-Website, Radio, Streaming, Web Modeling Language, Rancang Bangun

\section{PENDAHULUAN}

PT. Radio Memora Anoa Indah atau lebih dikenal dengan nama Memora FM Manado adalah salah satu stasiun radio di Manado dengan frekuensi 103.6 MHz. Memora FM Manado didirikan pada tahun 1978 dan merupakan anggota resmi dari Persatuan Radio Siaran Swasta Nasional Indonesia (PRSSNI). Segmentasi pasar dari Memora FM Manado yaitu kalangan anak muda perkotaan. Memora FM Manado juga mempunyai cabang di Gorontalo yakni Memora FM Gorontalo.

Memora FM Manado sebelumnya memiliki blog yang digunakan untuk melakukan post program-program on-air. Memora FM Manado sebelumnya juga sudah memiliki website namun hanya digunakan untuk menyiarkan program yang sedang on-air atau lebih dikenal dengan istilah audio streaming dan ada juga beberapa foto. Website tersebut tidak memiliki menu - menu seperti daftar program on- air atau off-air sehingga membuat pengunjung yang ingin mengetahui informasi tersebut harus melakukan aktivitas tambahan yaitu dengan membuka blog mereka. Tidak adanya music chart dalam website tersebut membuat pengguna tidak dapat mengetahui musik - musik yang sementara trend beserta peringkatnya dari Memora FM Manado. Selain itu, website tersebut juga tidak bisa menampilkan iklan Memora FM Manado dan informasi profil umum perusahaan yang dimaksud.

Berdasarkan uraian di atas, Memora FM Manado memerlukan sebuah website yang tidak hanya digunakan untuk melakukan audio streaming namun juga untuk memberikan informasi program on-air dan off- air, music chart, iklan dan beberapa fitur lainnya yakni daftar lowongan pekerjaan dan $e$ mail subscriptions. Adapun tujuan dalam penelitian ini adalah tidak lain untuk menjawab pokok permasalahan yaitu untuk merancang bangun website Memora FM Manado yang memiliki fitur audio streaming, menyediakan informasi program on-air dan off-air, menampilkan music chart, memiliki fitur untuk memasang iklan di website, dan menampilkan daftar lowongan pekerjaan serta terdapat fitur e-mail subscriptions.

\section{TINJAUAN PUSTAKA}

A. Website

Website adalah kumpulan halaman-halaman web yang saling berhubungan satu dengan yang lainnya yang dapat diakses di Internet melalui nama domain [13]. Berdasarkan sifatnya, website dapat dibagi menjadi website dinamis yakni yang isinya sering berubah dan yang jarang berubah disebut website statis. Berdasarkan tujuannya, website dapat dibagi menjadi personal, korporasi, portal, forum, e-Goverment, eBanking, e-Payment dan sebagainya. Berdasarkan bahasa pemrograman yang digunakan, website dapat dibagi menjadi Server Side yakni website yang bahasa pemrogramannya bergantung pada server dan yang tidak bergantung pada server disebut Client Side.

Adapun istilah-istilah yang terkait dengan website adalah sebagai berikut [9]:

1. World Wide Web atau yang sering disebut web merupakan kumpulan komputer dalam Internet yang sering disebut sebagai server yang menyediakan dokumen hypermedia (halaman yang dapat terdiri dari teks, grafik, audio dan video).

2. Dokumen hypermedia disebut juga halaman web.

3. Link Hypertext merupakan teks atau grafik yang menghubungkan antara halaman-halaman web.

4. Nama domain dapat diartikan sebagai alamat untuk membuka website.

\section{B. PHP: Hypertext Preprocessor}

Hypertext Preprocessor atau disingkat PHP [6] merupakan sebuah Bahasa scripting yang bersifat open-source yang bekerja di server. Dokumen PHP tidak dapat diproses oleh browser seperti dokumen javascript. Server memproses dokumen PHP kemudian mengirimnya ke dalam bentuk yang bisa dibaca oleh browser yakni dalam bentuk dokumen HTML. PHP dapat membuat website dinamis. PHP adalah juga 
interpreted language yang tidak perlu dikompilasi menjadi kode lainnya untuk dapat bekerja. Dengan tidak perlu dikompilasi maka memungkinkan pengubahan dan pengujian kode lebih cepat.

Fitur-fitur yang terdapat dalam PHP terbagi dalam 4 (empat) kategori yaitu sebagai berikut [5]:

1. Kepraktisan: PHP dimaksudkan untuk dapat mempercepat pembuatan aplikasi tanpa membutuhkan banyak pengetahuan. Contohnya, dokumen PHP dapat bekerja hanya dengan satu baris kode yakni seperti menampilkan tanggal dan waktu hari ini. Selain itu, PHP tidak memerlukan typecasting variable. Dengan kepraktisan tersebut, pembangun aplikasi dapat lebih fokus ke pembangunan aplikasi itu sendiri.

2. Tenaga: Tersedia banyak library bawaan ataupun dari pihak ketiga yang dapat mempercepat dalam pembangunan aplikasi. Contohnya adalah library untuk berkomunikasi dengan DBMS seperti MySQL. Selain itu, ada juga library untuk berkomunikasi dengan banyak protokol seperti IMAP dan POP3, membuat dan memanipulasi dokumen PDF dan masih banyak lagi.

3. Peluang: PHP menyediakan tidak hanya satu solusi terhadap suatu tugas yang akan dilakukan. Dalam hal paradigma pemrograman, PHP menyediakan dua paradigma yakni procedural dan berorientasi objek. Contoh lainnya adalah PHP tidak hanya dapat berkomunikasi dengan MySQL namun juga dengan DBMS lain seperti SQL Server, Oracle dan lainnya.

4. Harga: Tidak perlu mengeluarkan biaya untuk dapat menggunakan, memodifikasi ataupun mendistribusikan kembali versi PHP buatan sendiri.

\section{SAAS}

Syntactically Awesome Stylesheets atau disingkat SASS [10] merupakan ekstensi dari CSS yang membantu meringankan pembuatan dokumen CSS. SASS dapat menghilangkan pengulangan yang sering dilakukan dalam membuat kode CSS. Contohnya pengulangan penulisan nilai hexadecimal dari warna dengan memasukkannya ke dalam satu variable. Kode SASS yang ditulis di sebuah dokumen akan dikompilasi oleh SASS Engine menjadi kode CSS. SASS Engine ditulis dengan bahasa pemrograman Ruby.

Berikut ini adalah daftar lengkap dari fitur-fitur yang dimiliki oleh SAAS [11]:

1. Variables: bekerja seperti variable dalam bahasa pemrograman yang menyimpan suatu nilai dalam hal ini adalah nilai dari properti CSS.

2. Nesting: bekerja seperti nesting dalam bahasa pemrograman dalam hal ini yang dimasukkan ke dalam sarang adalah selector dari CSS.

3. Partials: memodularisasi dokumen SASS ke dalam bagian - bagian kecil di dokumen yang berbeda.

4. Mixims: bekerja seperti fungsi dalam bahasa pemrograman dalam hal ini mixim akan mengembalikan keluaran kumpulan properti CSS yang telah definisikan sesuai dengan argumen yang dimasukkan ketika dilakukan pemanggilan.

5. Extend/Inheritance: bekerja seperti pewarisan dalam bahasa pemrograman, dalam hal ini yang melakukan pewarisan adalah antara sesama selector dari CSS.

\section{Laravel}

Laravel merupakan framework pembangunan website dengan desain Model-View-Controller (MVC) untuk PHP [8]. Filosofi yang dipakai dalam mendesain framework ini adalah convention over configuration yang berarti terdapat beberapa konvensi yang disarankan untuk diikuti agar kode yang diperlukan dalam pembangunan aplikasi dapat menjadi lebih sedikit. Konvensi yang disarankan menyediakan minimalisasi tanpa mengurangi fungsionalitas.

Fitur-fitur laravel adalah sebagai berikut [7]:

1. Modularitas: Library dibagi menjadi modul - modul sendiri.

2. Testability: Memiliki fungsi - fungsi yang dapat membantu pengujian kode.

3. Routing: Dapat mendefinisikan rute bagi HTTP verbs (GET, POST, PUT dan DELETE) dari URL.

4. Manajemen konfigurasi: Pengaturan credential pada basis data atau alamat $e$-mail yang dipakai oleh aplikasi ada pada satu dokumen konfigurasi.

5. Query Builder dan ORM: Query Builder untuk melakukan operasi query basis data tanpa harus menulis SQL dan ORM (Object Relational Mapping) dengan nama Eloquent.

6. Template engine: Dengan nama Blade, yakni bahasa yang dapat menginjeksi variable ke dalam tampilan web yang akan dibuat.

7. E-Mailing: Dapat mengirim e-mail melalui web service seperti SendGrid, MailGun dan Mandrill.

8. Otentikasi: Menyediakan implementasi bawaan untuk membuat fitur otentikasi.

\section{E. Basis Data}

Basis Data secara umum adalah kumpulan data yang berhubungan [4]. Data dimaksudkan sebagai suatu fakta seperti nama hari atau alamat jalan. Data tersebut bisa disimpan dalam buku atau dokumen elektronik. Basis data yang terkomputerisasi merupakan basis data yang dibentuk dan dikontrol menggunakan program yang disebut Database Management System (DBMS).

Basis data yang terkomputerisasi atau hanya disebut basis data merupakan struktur dokumen yang terdapat pada komputer yang terdiri dari data dan metadata yang terintegrasi dan dapat dipakai bersamaan [3]. Struktur dokumen tersebut menyimpan data dan metadata. Metadata merupakan informasi yang memberikan penjelasan mengenai data seperti nama dan tipenya. Contoh metadata nama dan tipe data dari data "Altiano" yakni "Nama Mahasiswa" dan "Karakter".

Model data yang dipakai dalam pembangunan Website Memora FM Manado adalah model hubungan entitas. Model data merupakan representasi sederhana atau abstraksi dari struktur data yang ada di dunia nyata [3]. Model hubungan entitas adalah pengembangan dari model relational yang mempermudah pemodelan data dengan mengambarkan hubungan antara tabel atau disebut juga entitas. Model relational sendiri adalah model yang berdasar pada konsep matematika yakni relasi dimana data dibagi menjadi tabel-tabel yang saling terhubung atau memiliki relasi.

MySQL [12] merupakan DBMS untuk model basis data relational yang bersifat open-source dengan lisensi GNU/GPL (General Public License). Bahasa yang digunakan MySQL untuk mengakses basis data adalah Structured Query Language 
(SQL). MySQL ditulis dengan bahasa pemrograman $\mathrm{C}$ dan $\mathrm{C}++$. MySQL juga menyediakan API bagi bahasa pemrograman untuk mengakses programnya. Tipe data yang didukung oleh MySQL adalah numerik, string dan penanggalan dan waktu.

\section{F. Model Hubungan Entitas}

Model hubungan entitas [3] bisa digambarkan dengan Entity Relationship Diagram (ERD). Notasi ERD yang dipakai dalam pembangunan Website Memora FM Manado adalah notasi crow's foot.

Berikut ini adalah penjelasan komponen-komponen dalam model hubungan entitas:

1. Entitas: Tabel yang memiliki kumpulan baris data (entity instance). Nama entitas tidak boleh berbentuk plural. Contoh entitas yakni MAHASISWA dan contoh entity instance-nya adalah mahasiswa dengan nama "Altiano".

2. Atribut: Karakteristik dari entity instance. Contohnya, nama mahasiswa, alamat mahasiswa dan e-mail mahasiswa.

3. Hubungan: Asosiasi antar entitas. Hubungan menggunakan kata kerja pasif atau aktif. Contohnya: MAHASISWA mengontrak MATA KULIAH.

\section{G. Hypertext Schema}

Hypertext schema merupakan antarmuka halaman web [1]. Definisi antarmuka yang dimaksud adalah pengorganisasian secara internal komponen-komponen yang akan menampilkan isi halaman web (content unit). Definisi lainnya adalah links yang menghubungkan antar halaman web dan antar content unit di dalamnya. Komponen dalam website juga dapat melakukan operasi seperti manajemen content atau prosedur login/logout. Komponen seperti itu disebut operation unit.

Berikut ini adalah penjelasan mengenai elemen yang ada dalam hypertext schema:

1. Site view: Bagian yang didesain untuk menyelesaikan suatu kumpulan kebutuhan tertentu.

2. Area: Bagian dalam site view yang mengelompokkan page.

3. Page: Halaman web yang memiliki informasi.

a. Home page: Halaman awal ketika pengguna mengakses website. Dilambangkan dengan huruf " $\mathrm{H}$ ".

b. Default page: Halaman awal ketika pengguna masuk ke suatu area. Dilambangkan dengan huruf "D".

c. Landmark page: Halaman yang dapat diakses oleh page lain dalam modul (site view atau area) yang membungkusnya. Dilambangkan dengan huruf "L".

4. Content Unit: Komponen dalam page yang berperan dalam menampilkan content.

a. Index unit: Daftar entity instance disertai dengan key deskriptif dan dapat dipilih oleh pengguna.

b. Data unit: Beberapa atribut dari entity instance.

c. Multidata unit: Beberapa atribut dari kumpulan entity instance.

d. Scroller unit: Kumpulan entity instance yang dapat dijelajahi.

e. Entry unit: Menampilkan form untuk menerima input.

5. Link: Penghubung antar page dan antar content unit.

a. Automatic Link: Menampilkan content unit tertentu bersamaan dengan content unit yang dipilih. Dilambangkan dengan huruf " $A$ ". b. Transport Link: Mengirimkan informasi ke content unit tertentu tanpa perlu interaksi dari pengguna.

c. OK Link: Menghubungkan operation unit ketika operasi berhasil.

d. KO Link: Menghubungkan operation unit ketika operasi gagal.

6. Global Parameter Unit: Mengatur informasi yang tersedia secara global atau dapat diakses oleh semua page.

a. Set unit: Menyimpan informasi global.

b. Get unit: Mengambil informasi global.

7. Operation Unit: Melakukan service atau manajemen content.

a. Create unit: Menambahkan entity instance.

b. Delete unit: Menghapus entity instance.

c. Modify unit: Mengubah entity instance.

d. Connect unit: Menambah relasi dari entity instance.

e. Disconnect unit: Menghapus relasi dari entity instance.

f. Login unit: Melakukan verifikasi pengguna.

g. Logout unit: Menutup sesi dari pengguna terhadap website.

h. Generic unit: Menjalankan service diluar konteks dari website.

\section{METODE PENELITIAN}

Metode yang digunakan dalam pengembangan sistem adalah Web Modeling Language (WebML). Definisi dari WebML [2] yakni sebuah metode pengembangan yang membantu menentukan struktur, organisasi, dan presentasi halaman web dari aplikasi web. Bagian utama dari WebML adalah gabungan beberapa konsep untuk pembangunan aplikasi web khususnya yang memiliki pengolahan data yang insentif. Gabungan konsep yang dimaksud adalah gabungan konsep pemodelan yang umum dipakai dalam pengembangan yakni use case dan activity diagram dari UML dan model hubungan entitas dengan konsep baru untuk mendesain halaman web yakni hypertext schema.

Adapun fase-fase dalam WebML bersifat iterative, maksudnya dapat dilakukan berulang-ulang sampai aplikasi web memenuhi kebutuhan yang ditentukan. Lingkup iterasi yang dimaksudkan adalah dari fase analisis kebutuhan sampai fase pengujian dan evaluasi. Setiap iterasi dari fase-fase WebML dapat menghasilkan prototype atau sebagian fungsi dari aplikasi web. Fase analisis dan desain menghasilkan model konseptual dan merupakan fokus utama dalam WebML. Model konseptual yang dihasilkan akan membantu fase-fase selanjutnya dalam pengembangan. Gambar 1 menunjukkan keseluruhan fase dalam WebML.

Tujuan dari fase-fase dalam metode WebML adalah sebagai berikut [2]:

1. Analisis Kebutuhan bertujuan untuk mendapatkan spesifikasi kebutuhan. Tahapan tersebut adalah:

a. Identifikasi tipe pengguna

b. Tentukan kebutuhan fungsional dalam bentuk use cases dan jika perlu dengan activity diagram

c. Identifikasi objek informasi utama dalam bentuk kamus data

d. Lakukan pembagaian site view 
e. Tentukan aturan presentasi halaman web

f. Spesifikasi kebutuhan non-fungsional

2. Desain aplikasi terdiri dari dua sub-fase yakni desain data untuk mendapatkan model hubungan entitas dan desain hypertext untuk mendapatkan hypertext schema.

3. Implementasi untuk mendapatkan basis data dan aplikasi.

4. Pengujian dan evaluasi untuk menguji fungsionalitas aplikasi dengan menggunakan white box testing, menguji performa dari aplikasi dan menguji desain aplikasi kepada pengguna untuk melihat seberapa baik aplikasi dipakai (usability evaluation) dengan menggunakan metode user testing.

5. Deployment aplikasi web kemudian perawatan dan evolusi untuk melihat kesalahan dari aplikasi web dan memperbaikinya juga untuk menambahkan kebutuhan baru. Perubahan yang disebabkan oleh kesalahan atau penambahan kebutuhan akan mengubah juga model konseptual pada fase desain aplikasi.

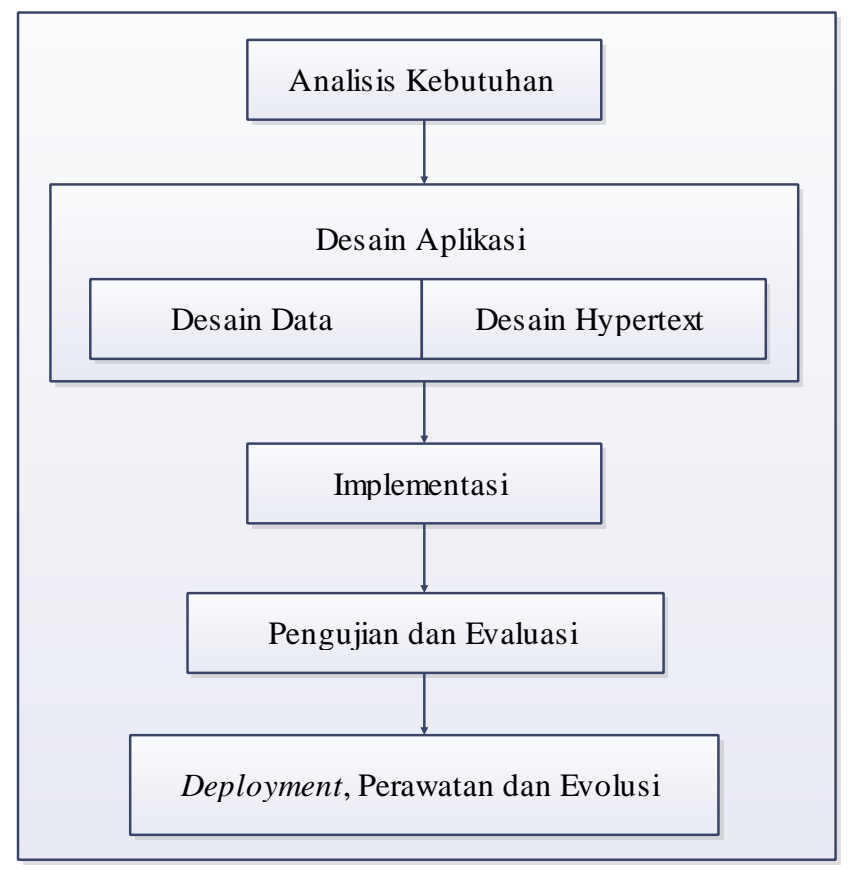

Gambar 1. Fase-fase dalam WebML [2]

\section{HASIL DAN PEMBAHASAN}

A. Desain Aplikasi

Fase ini dibagi menjadi 2 sub-fase yakni desain data dan desain hypertext. Desain data bertujuan untuk mendapatkan model hubungan entitas dengan notasi crow's foot berdasarkan spesifikasi kamus data. Desain hypertext bertujuan untuk mendapatkan hypertext schema berdasarkan spesifikasi use case, spesifikasi site view dan model hubungan entitas.

Spesifikasi kamus data berisikan rincian dari objek-objek data, atau disebut juga entitas, yang terdapat pada website Memora FM Manado. Entitas bisa memiliki sinonim yang dimaksudkan untuk mempermudah penamaan. Baris properties merupakan daftar atribut dari entitas. Baris relasi merupakan hubungan entitas tersebut dengan entitas lain. Baris komponen merupakan tabel basis data yang muncul dikarenakan entitas memiliki atribut berjenis multi-valued. Objek-objek data tersebut antara lain: Admin, Company Profile, Program, Program Crew, Event, Event Type, Ads, Advertizer, Career, Crew, Crew Permission, Permission, Audio Streaming, Request, Request Authentication, Subscriber, Email Subscription, Subscription Item, Music, Music Chart.

Spesifikasi site view mendeskripsikan kumpulan halaman web dalam hubungannya kebutuhan fungsional yang telah dispesifikasi oleh use case. Ada dua site view dari website Memora FM Manado yakni admin site view dan visitor site view. Kumpulan halaman web dikelompokan ke dalam area dan disertai dengan prioritas pembuatan. Setiap area juga memiliki objek data yang dapat diatur atau hanya sekedar diakses. Untuk admin site view ada tiga area yang dispesifikasi yakni area programs, events dan music chart sedangkan untuk visitor view, semua areanya dispesifikasi.

\section{Desain Data}

Entity Relationship Diagram (ERD) yang diperoleh dari sub-fase ini akan menjadi panduan dalam membuat basis data dari website. Label PK berarti atribut dari tabel adalah primary key sedangkan FK berarti atribut tersebut adalah foreign key. Atribut created_at, updated_at dan deleted_at adalah atribut khusus yang tidak memiliki prefix. Secara berurutan, atribut ini dipakai untuk mengetahui waktu pembuatan, pengubahan atau penghapusan dari entity instance. Atribut created_at tidak bisa memiliki nilai NULL sedangkan dua atribut sisanya bisa. Tabel Admin, Company Profile, Audio Streaming dan Career adalah tabel-tabel yang tidak memerlukan relasi dengan tabel lain. Keseluruhan tabel dapat ditunjukkan pada Gambar 2.

\section{Desain Hypertext}

Hasil dari desain hypertext adalah menghasilkan hypertext schema yang menggambarkan pengorganisasian content dari setiap halaman web. Hypertext schema berperan sebagai panduan dalam mengimplementasi website. Ada dua site view yang terdapat pada hypertext schema dari website Memora FM Manado yakni admin site view dan visitor site view. Admin site view dibagi menjadi area-area yang dapat dilihat pada Gambar 3 sampai Gambar 13. Untuk visitor site view, Gambar 14 menunjukkan semua area yang terdapat dalam site view ini. Setiap halaman dalam visitor site view memiliki bagian yang bertuliskan "global" yang merupakan kumpulan unit yang selalu muncul beserta halaman request. Bagian global dapat dilihat pada Gambar 15. 


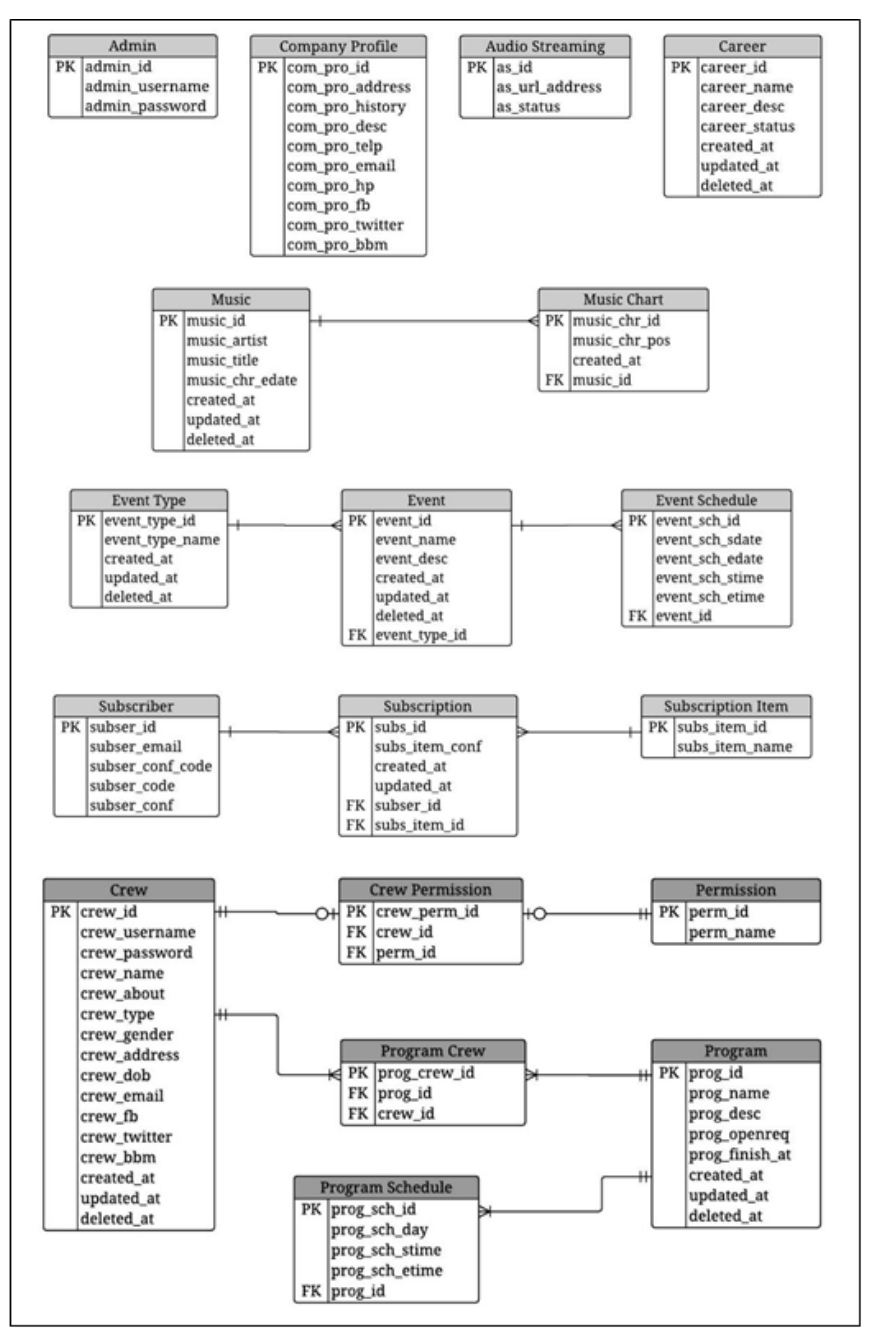

Gambar 2. Entity Relationship Diagram untuk basis data

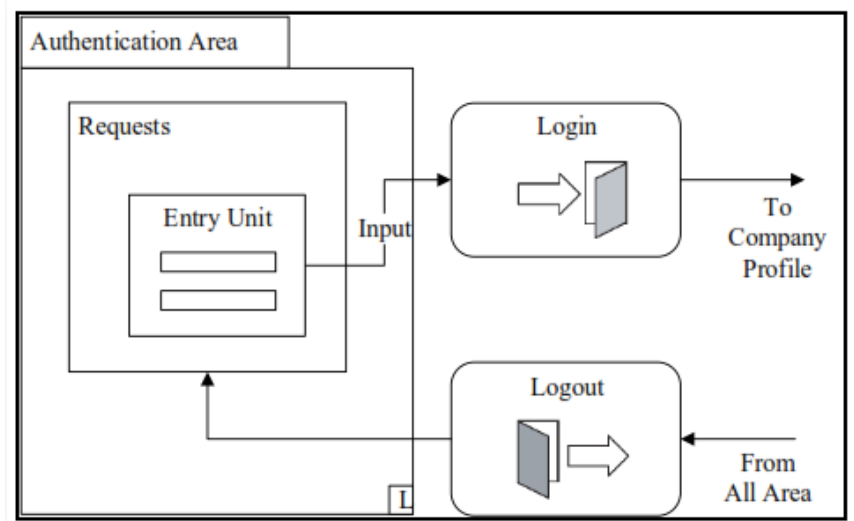

Gambar 3. Hypertext schema area Authentication

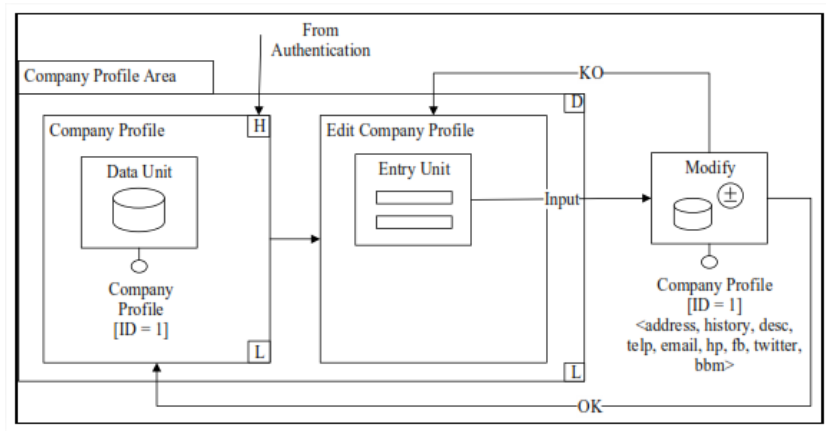

Gambar 4. Hypertext schema area Company Profile

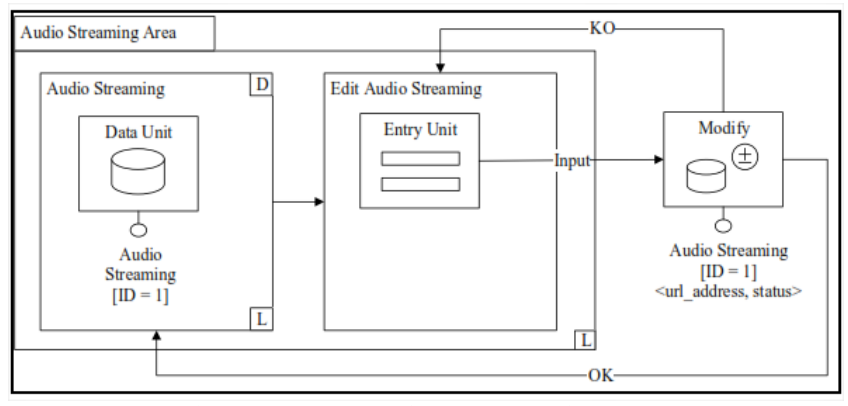

Gambar 5. Hypertext schema area Audio Streaming

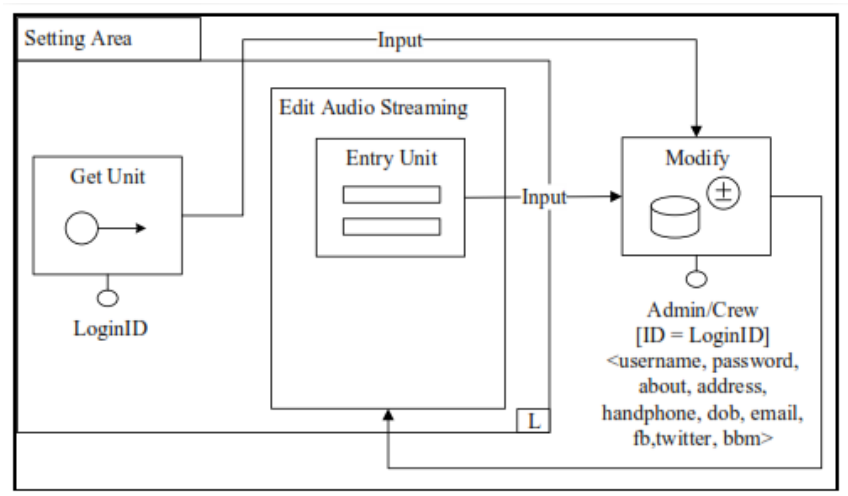

Gambar 6. Hypertext schema area Setting

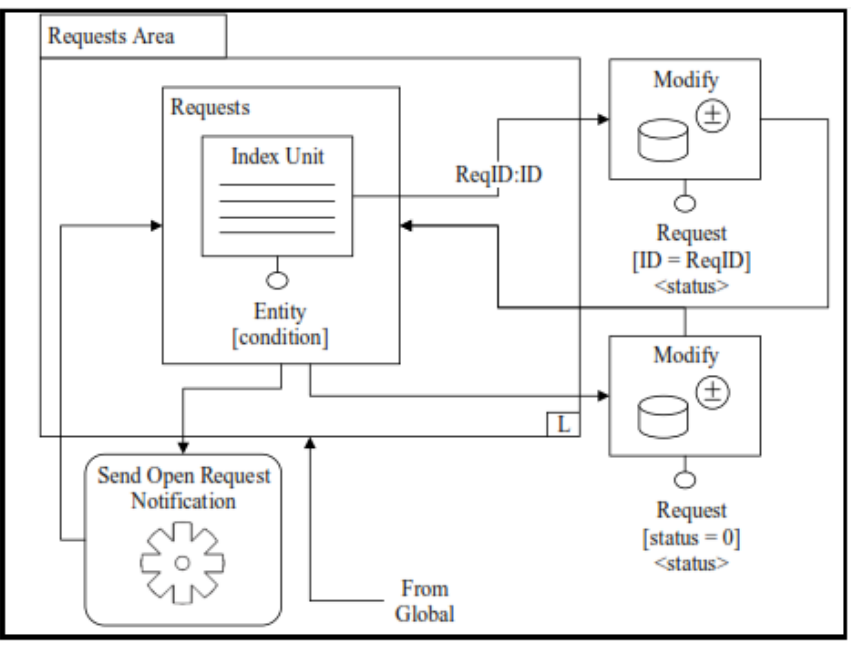

Gambar 7. Hypertext schema area Requests 


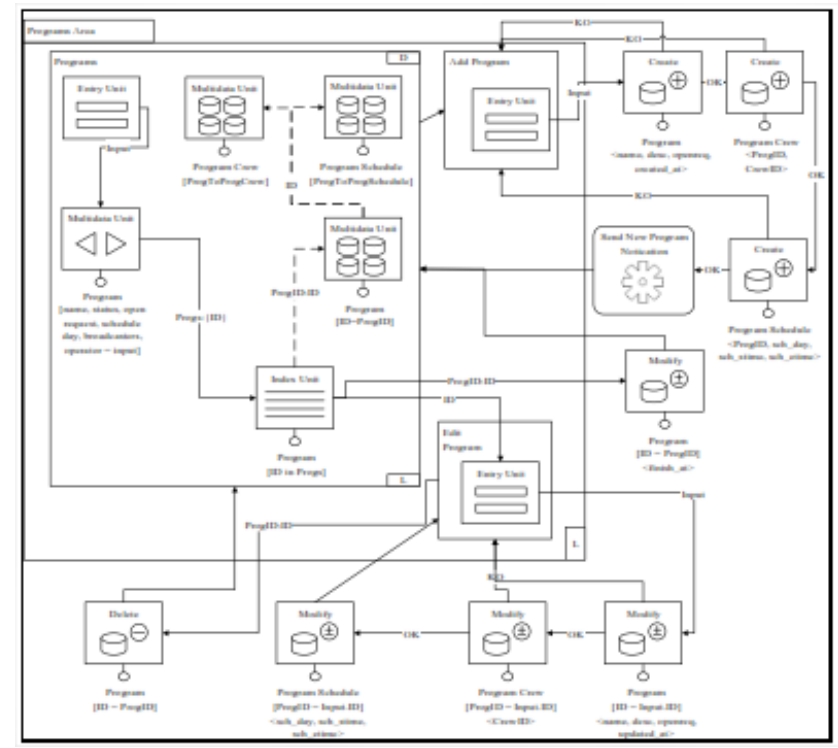

Gambar 8. Hypertext schema area Programs

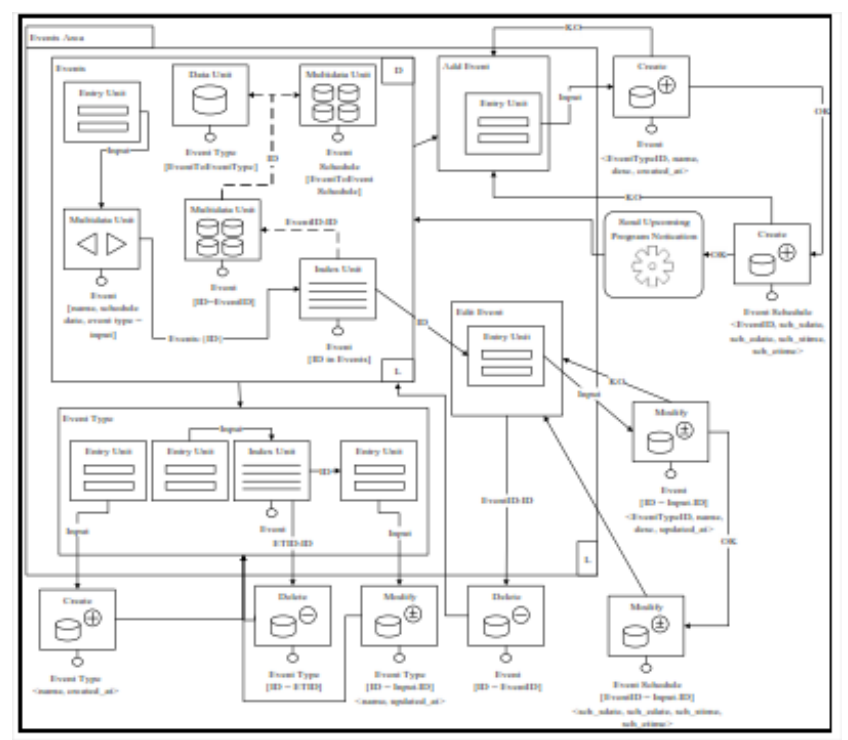

Gambar 9. Hypertext schema area Events

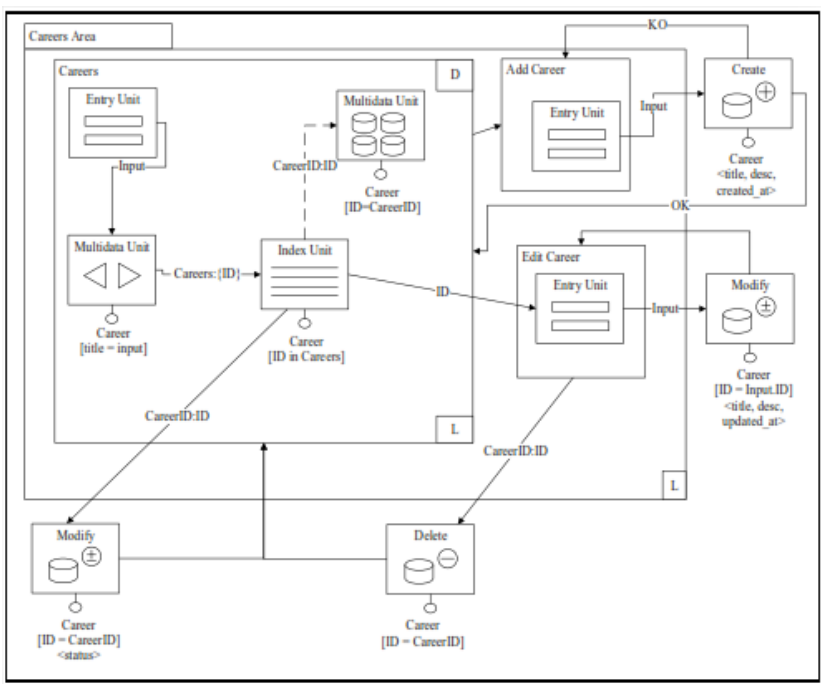

Gambar 10. Hypertext schema area Careers

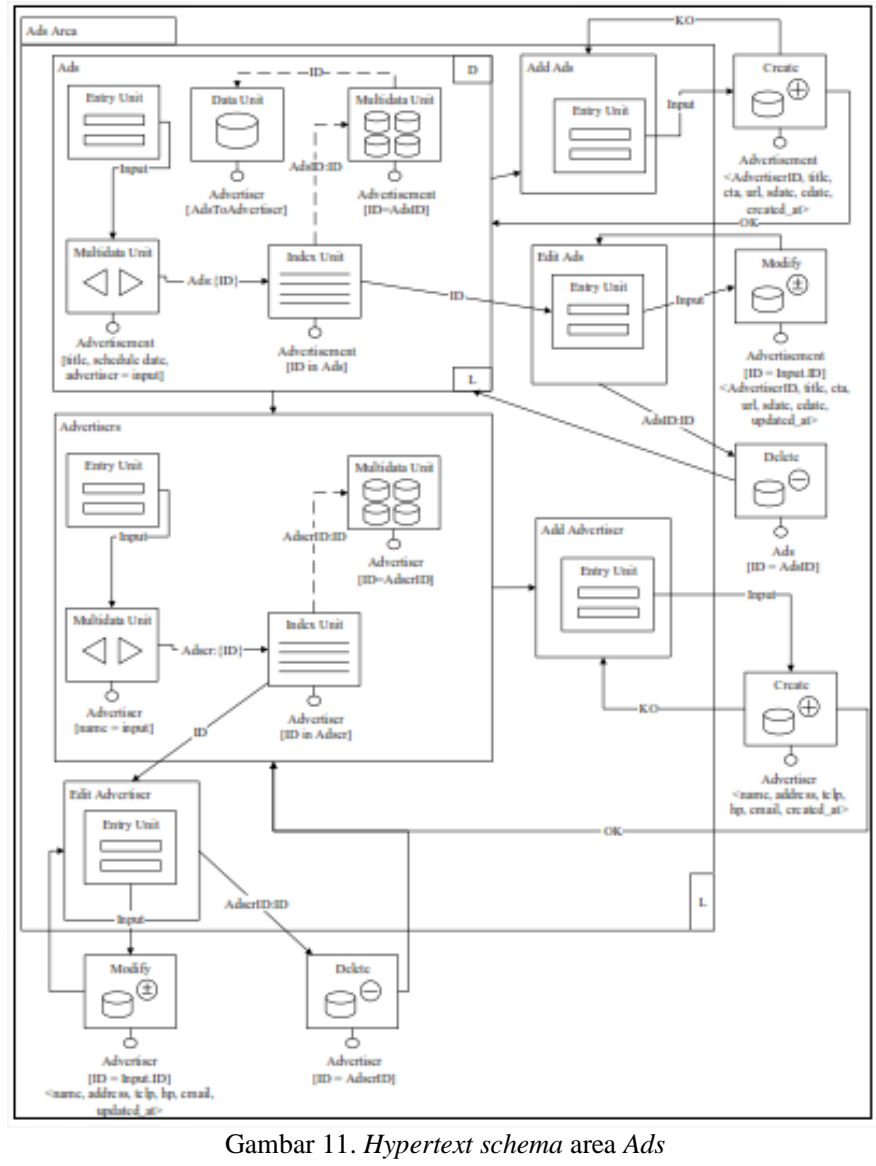

Gambar 11. Hypertext schema area Ads

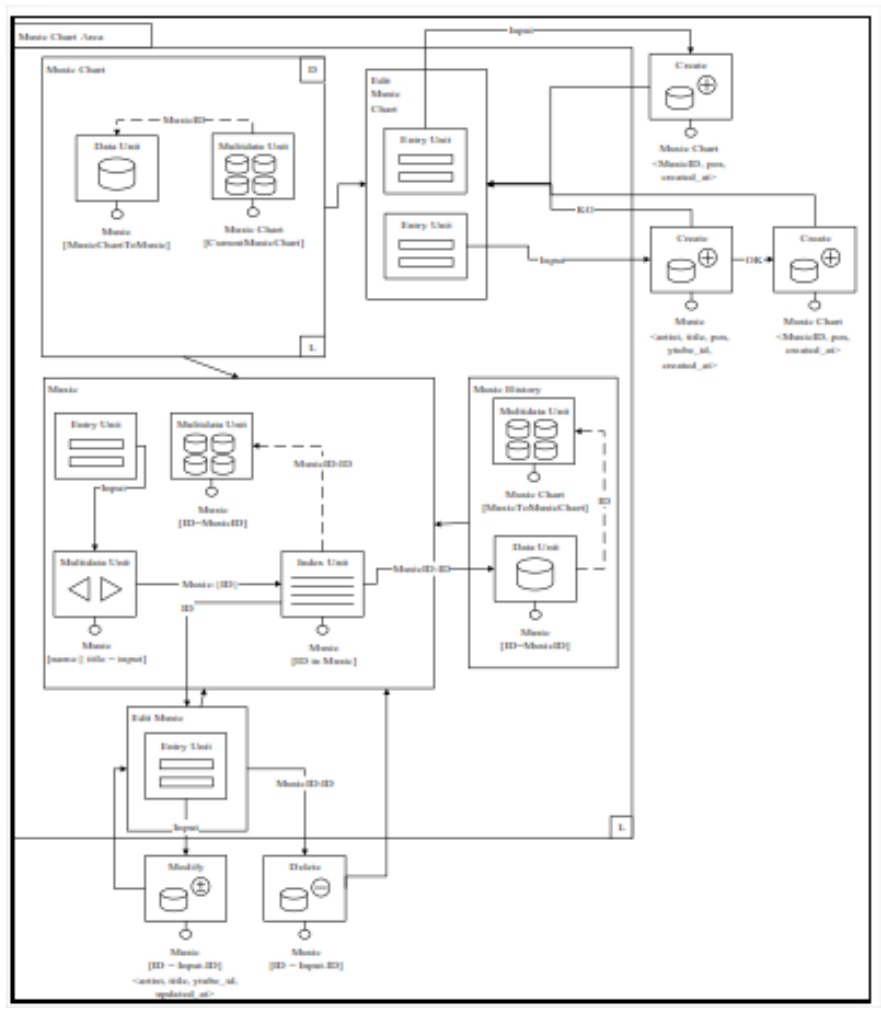

Gambar 12. Hypertext schema area Music Chart 


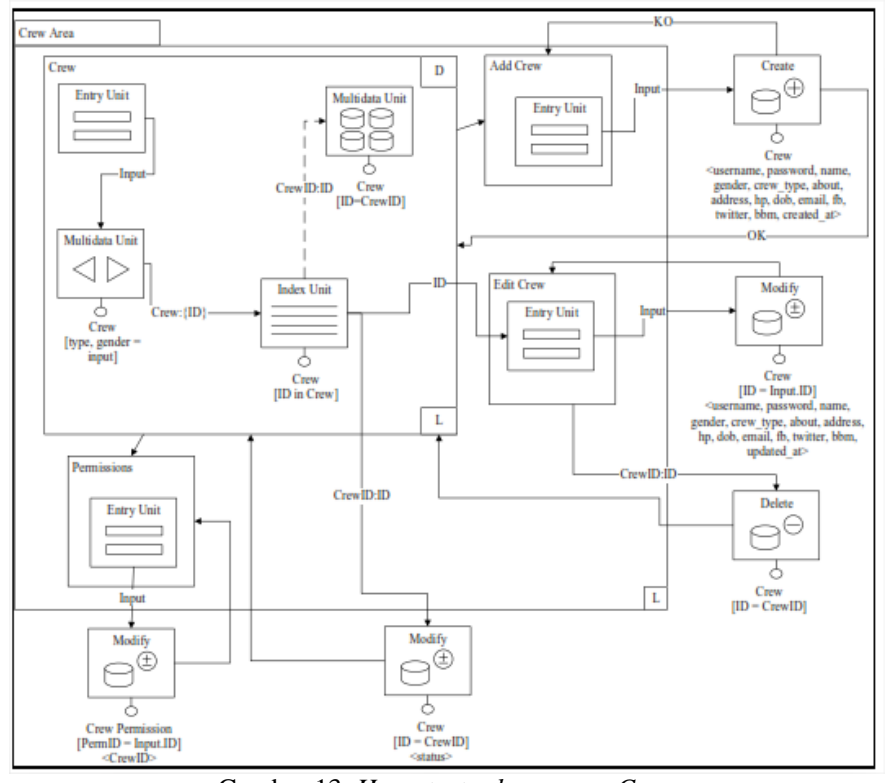

Gambar 13. Hypertext schema area Crew

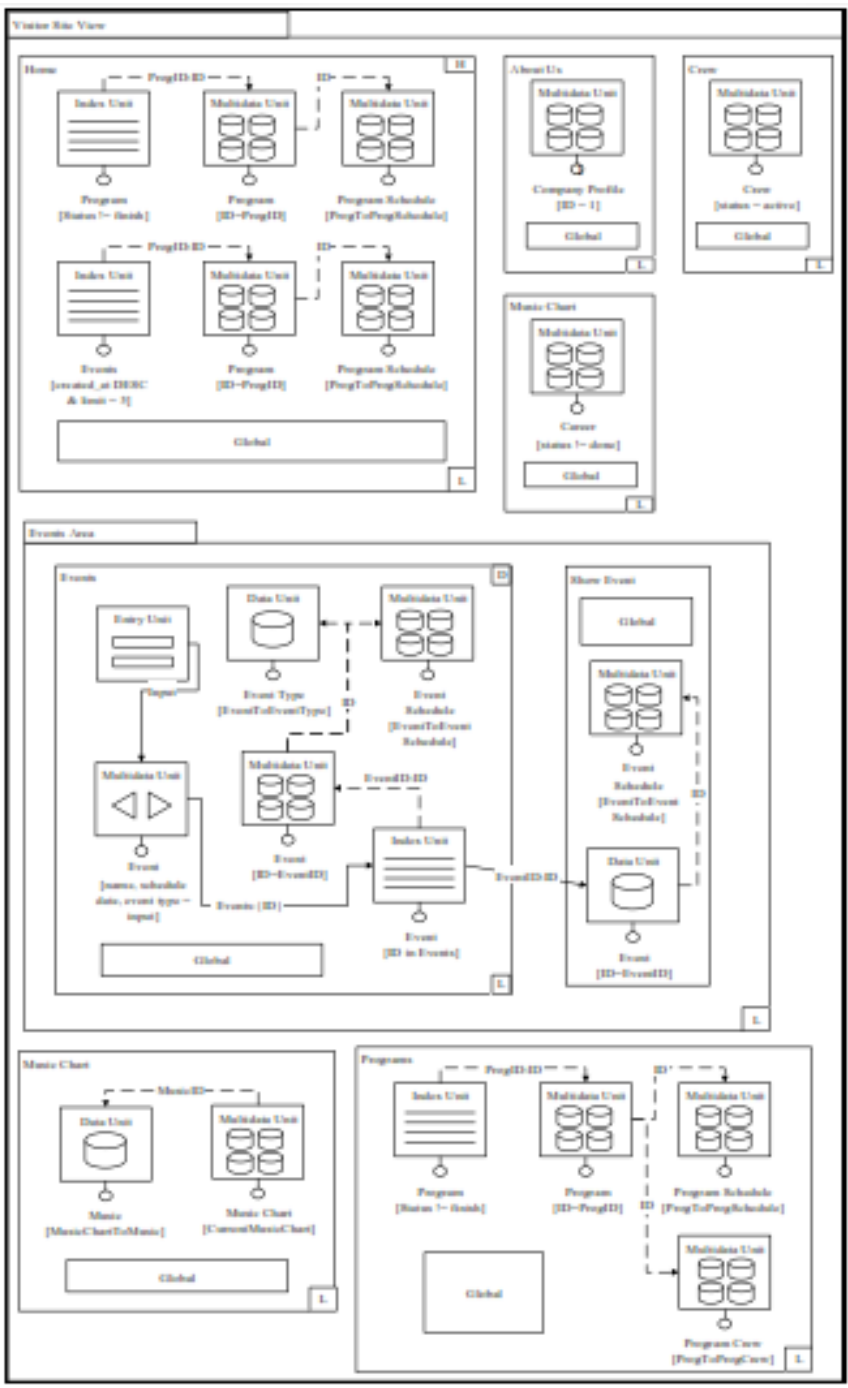

Gambar 14. Hypertext schema untuk Visitor Site View

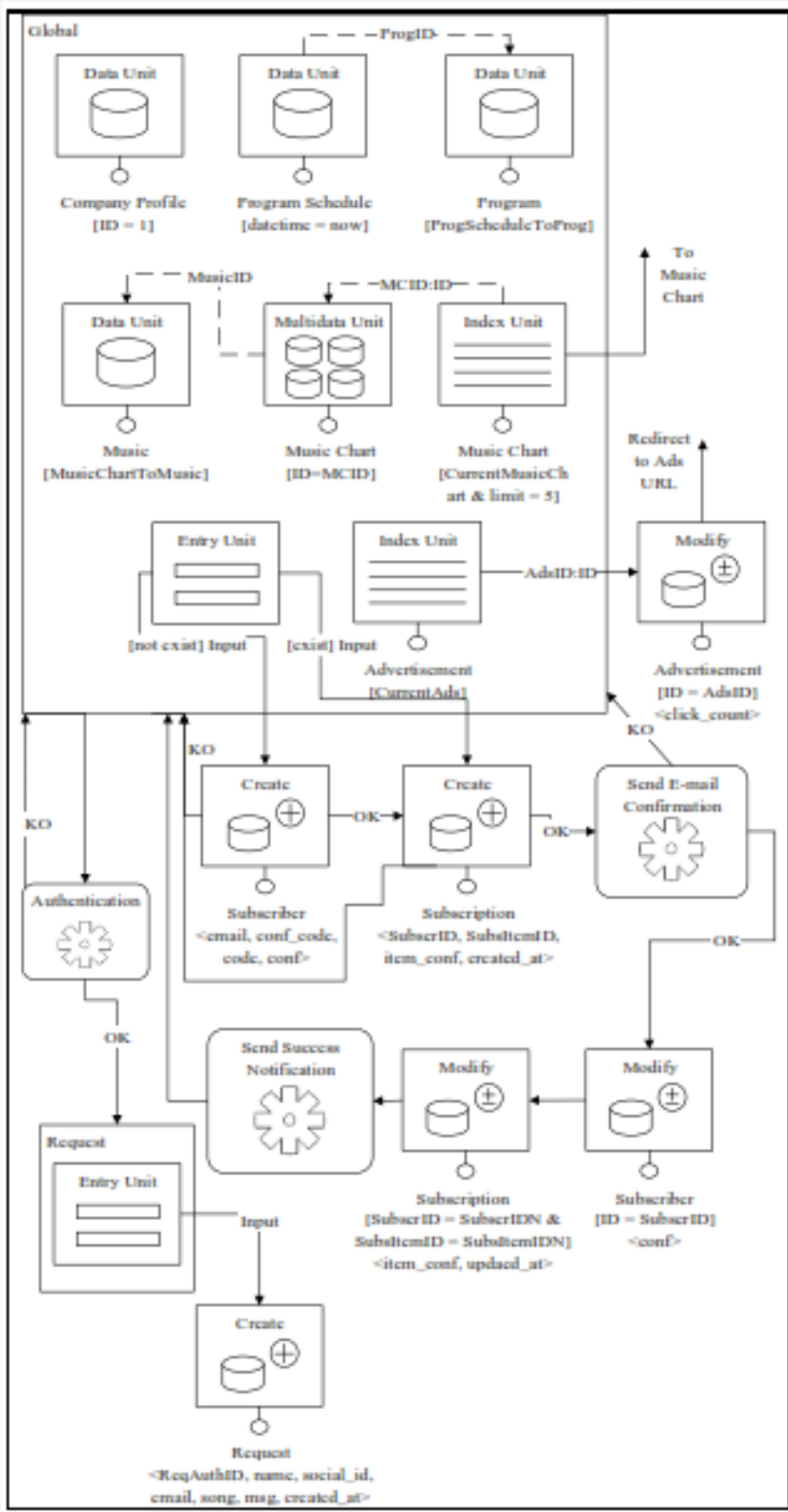

Gambar 15 Hypertext schema bagian Global Visitor Site View

\section{B. Implementasi}

Fase implementasi merupakan fase yang akan menerapkan hypertext schema yang didapatkan dari fase desain aplikasi. Implementasi website untuk bagian admin dapat dilihat pada Gambar 16 sampai Gambar 18. Sedangkan untuk implementasi website bagian pengunjung (user) dapat dilihat pada Gambar 19 dan Gambar 20. 

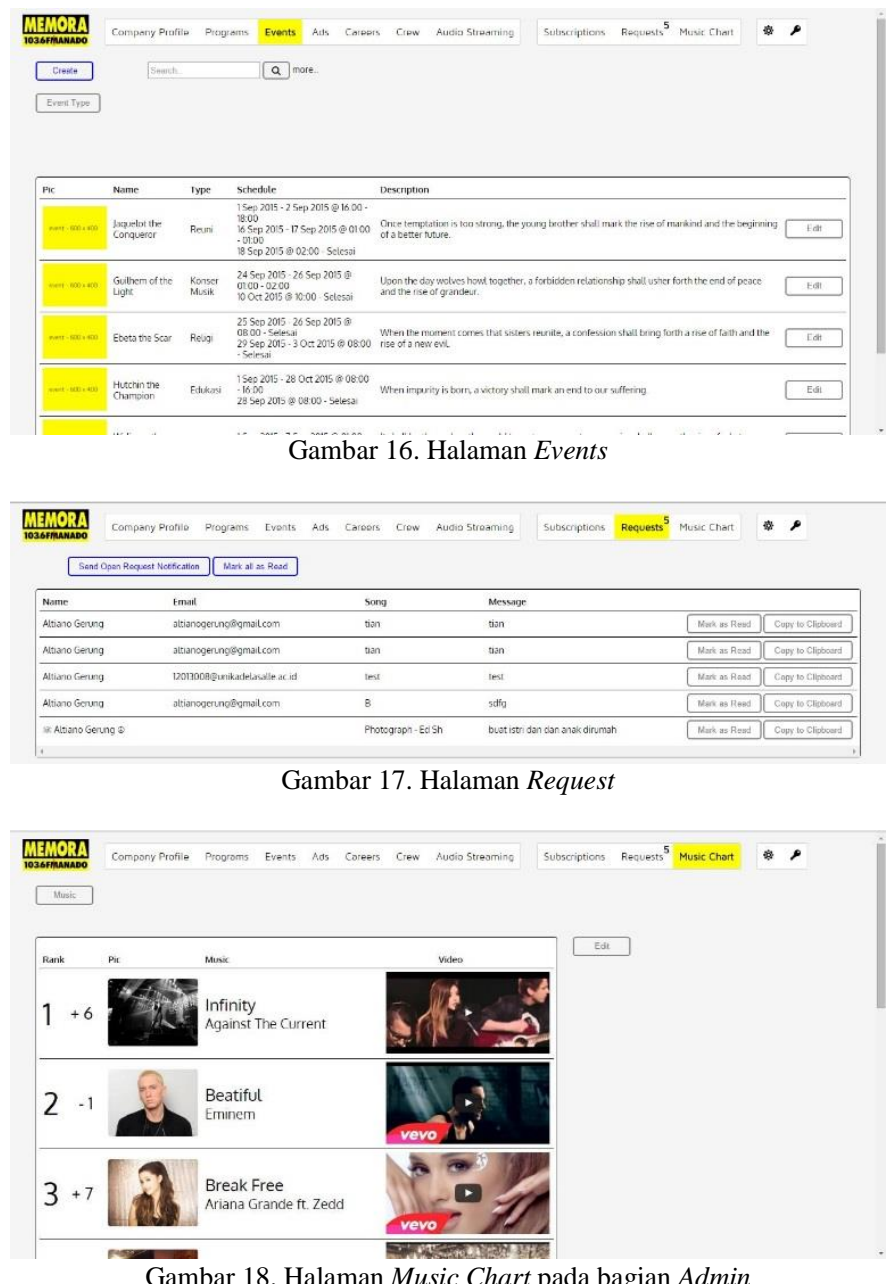

Gambar 18. Halaman Music Chart pada bagian Admin

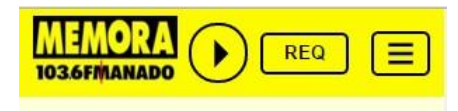

\section{Programs}

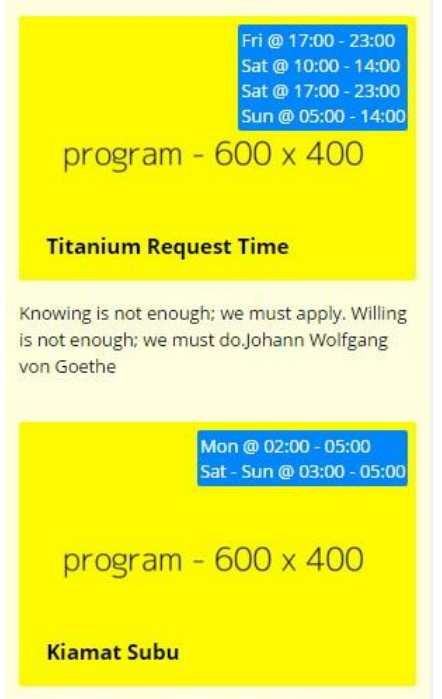

What you do today can improve all your tomorrows.Ralph Marston

Gambar 19. Halaman Home (versi Mobile)

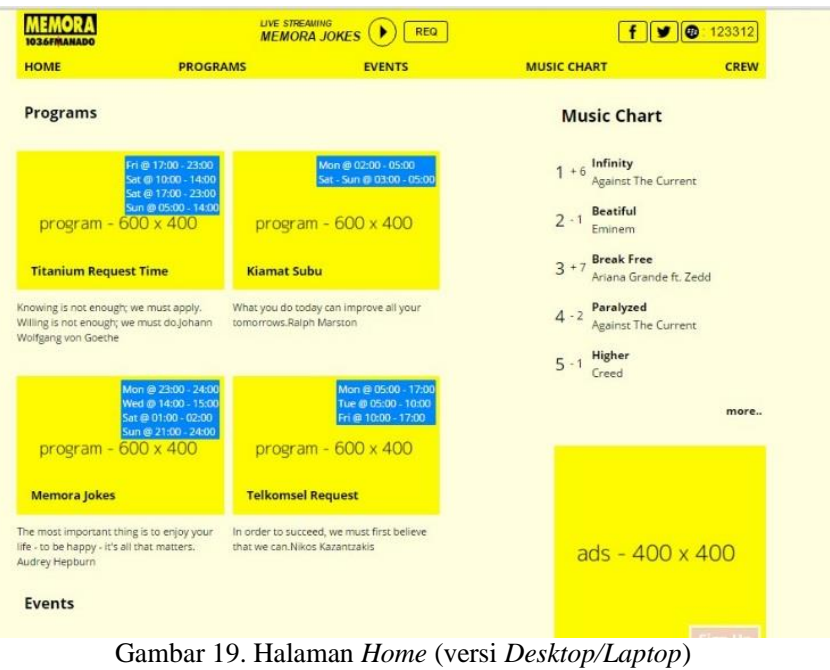

C. Pengujian dan Evaluasi

Fase pengujian dan evaluasi adalah fase dimana implementasi yang telah dilakukan sebelumnya diuji untuk memastikan website telah memenuhi kebutuhan yang dispesifikasi. Fase pengujian dibagi menjadi dua bagian yakni pengujian fungsional dan pengujian performa. Pengujian performa dilakukan ketika website telah di-deploy ke server. Pengujian fungsional yang menguji apakah kebutuhan fungsional yang dispesifikasi telah dipenuhi akan dibuat menggunakan white box testing. Evaluasi dilakukan menggunakan user testing.

\section{White Box Testing}

Pembangunan website Memora FM Manado menggunakan framework Laravel sehingga pembagian white box testing akan disesuaikan dengan struktur dari framework ini. Dokumen controller merupakan dokumen inti yang mengatur proses kerja dari website. Kolom algoritma merupakan langkah-langkah logis yang digunakan untuk mencapai tujuan dari method yang ada pada dokumen controller. Test case merupakan kumpulan kasus uji coba yang dilakukan dalam eksekusi algoritma. Tabel 1 sampai Tabel 5 menunjukkan pengujian White Box Testing pada dokumen controller.

Tabel 1. White Box Testing pada Aunthentication Controller

\begin{tabular}{|c|c|c|}
\hline Method & Algoritma & Test case \\
\hline $\operatorname{get} \operatorname{Login}()$ & 1. Tampilkan halaman login. & \\
\hline $\begin{array}{l}\text { postLogin(Reques } \\
\text { t \$request) }\end{array}$ & $\begin{array}{l}\text { 1. Lakukan validasi input. } \\
\text { 2a. Jika pengguna tidak } \\
\text { terdaftar maka tampilkan } \\
\text { halaman login dengan pesan } \\
\text { error dan selesai. } \\
\text { 2b. Jika terdaftar, simpan } \\
\text { variable login, } \text { username, } \\
\text { user_id ke session. } \\
\text { 3a. Jika pengguna adalah } \\
\text { admin maka redirect ke } \\
\text { halaman company profile dan } \\
\text { selesai. } \\
\text { 3b. Jika pengguna adalah } \\
\text { crew } \\
\text { maka dapatkan data crew. }\end{array}$ & $\begin{array}{l}\text { 1. Input } \\
\text { username } \\
\text { atau password } \\
\text { kosong. } \\
\text { 2a. Pengguna } \\
\text { tidak terdaftar. } \\
\text { 2b. Pengguna } \\
\text { terdaftar. } \\
\text { 3a. Pengguna } \\
\text { adalah admin. } \\
\text { 3b. Pengguna } \\
\text { bukan admin. } \\
\text { 4a. Crew } \\
\text { memiliki } \\
\text { status aktif. }\end{array}$ \\
\hline
\end{tabular}




\begin{tabular}{|c|c|c|}
\hline & $\begin{array}{l}\text { 4a. Jika crew memiliki } \\
\text { status } \\
\text { aktif, redirect ke } \\
\text { halaman } \\
\text { requests. } \\
\text { 4b. Jika tidak, tampilkan } \\
\text { halaman } \\
\text { login dengan pesan error. }\end{array}$ & $\begin{array}{l}\text { 4b. Crew } \\
\text { memiliki } \\
\text { status tidak } \\
\text { aktif. }\end{array}$ \\
\hline getLogout() & $\begin{array}{l}\text { 1. Hapus variable login } \\
\text { dan } \\
\text { isAdmin dari session. } \\
\text { 2. Redirect ke halaman login. }\end{array}$ & \\
\hline visitorSignIn(\$id) & $\begin{array}{l}\text { 1a. Jika nilai parameter } \\
\text { id merupakan Facebook, } \\
\text { Twitter atau Google maka isi } \\
\text { nilai variable vsignin pada } \\
\text { session dan lakukan redirect ke } \\
\text { halaman otentikasi dari service } \\
\text { yang dituju. } \\
\text { 1b. Jika tidak, tampilkan } \\
\text { halaman error } 404 \text {. }\end{array}$ & $\begin{array}{l}\text { 1a. Nilai } \\
\text { parameter id } \\
\text { salah satu dari } \\
\text { Facebook, } \\
\text { Twitter atau } \\
\text { Google. } \\
\text { 1b. Nilai } \\
\text { parameter } \\
\text { tidak } \\
\text { diketahui. }\end{array}$ \\
\hline $\begin{array}{l}\text { signInCallback }(\$ i \\
\text { d) }\end{array}$ & $\begin{array}{l}\text { 1. Jika variable vsignin } \\
\text { kosong, } \\
\text { tampilkan halaman } \text { error } 404 \\
\text { dan selesai. } \\
\text { 2. Jika nilai parameter id } \\
\text { merupakan Facebook, Twitter } \\
\text { atau Google maka isi nilai } \\
\text { variable req_auth_id pada } \\
\text { session dan dapatkan data } \\
\text { pengunjung dari service. } \\
\text { 3. Redirect ke halaman } \\
\text { request. }\end{array}$ & $\begin{array}{l}\text { 1a. Nilai } \\
\text { variable } \\
\text { vsignin } \\
\text { kosong. } \\
\text { 1b. Nilai } \\
\text { variable } \\
\text { vsignin tidak } \\
\text { kosong. } \\
\text { 2a. Nilai } \\
\text { parameter id } \\
\text { salah satu dari } \\
\text { Facebook, } \\
\text { Twitter atau } \\
\text { Google. } \\
\text { 2b. Nilai } \\
\text { parameter } \\
\text { tidak } \\
\text { diketahui. }\end{array}$ \\
\hline
\end{tabular}

Tabel 2. White Box Testing pada Permission Controller

\begin{tabular}{|c|c|c|}
\hline Method & Algoritma & Test case \\
\hline index() & $\begin{array}{l}\text { 1. Tampilkan halaman } \\
\text { permissions berserta data } \\
\text { crew, crew permission } \\
\text { dan permission. }\end{array}$ & $\begin{array}{l}\text { 1. Ubah nilai } \\
\text { dari } \\
\text { target data. }\end{array}$ \\
\hline $\begin{array}{l}\text { update(Request } \\
\text { \$request) }\end{array}$ & $\begin{array}{l}\text { 1. Hapus semua data } \text { crew } \\
\text { permission. } \\
\text { 2. Tambahkan crew } \\
\text { permission baru berdasarkan } \\
\text { parameter } \text { request. } \\
\text { 3. Redirect ke halaman } \\
\text { permissions } \\
\text { dengan pesan berhasil. }\end{array}$ & $\begin{array}{l}\text { 2. Ubah nilai } \\
\text { dari } \\
\text { parameter. }\end{array}$ \\
\hline
\end{tabular}

Tabel 3. White Box Testing pada Audio Streaming Controller

\begin{tabular}{|l|l|l|}
\hline Method & Algoritma & Test case \\
\hline index() & $\begin{array}{l}\text { 1. Tampilkan halaman audio } \\
\text { streaming berserta data audio } \\
\text { streaming. }\end{array}$ & $\begin{array}{l}\text { 1. Ubah nilai } \\
\text { dari } \\
\text { target data. }\end{array}$ \\
\hline
\end{tabular}

\begin{tabular}{|l|l|l|}
\hline edit() & $\begin{array}{l}\text { 1. Tampilkan halaman ubah } \\
\text { audio } \\
\text { streaming berserta data } \\
\text { audio streaming. }\end{array}$ & $\begin{array}{l}\text { 1. Ubah nilai } \\
\text { dari } \\
\text { target data. }\end{array}$ \\
\hline $\begin{array}{l}\text { update(Request } \\
\text { \$request) }\end{array}$ & $\begin{array}{l}\text { 1. Lakukan validasi input. } \\
\text { 2. Simpan data audio } \\
\text { streaming ardasarkan paramter request. } \\
\text { berdastas kosong. }\end{array}$ & $\begin{array}{l}\text { 1a. Input } \\
\text { arl_address } \\
\text { stau }\end{array}$ \\
\hline
\end{tabular}

Tabel 4. White Box Testing pada Setting Controller

\begin{tabular}{|c|c|c|}
\hline Method & Algoritma & Test case \\
\hline getSetting() & $\begin{array}{l}\text { 1a. Jika pengguna adalah } \\
\text { crew maka tampilkan halaman } \\
\text { setting dengan data crew. } \\
\text { 1b. Jika tidak, tampilkan } \\
\text { halman setting dengan hanya } \\
\text { input username dan password. }\end{array}$ & $\begin{array}{l}\text { 1a. Pengguna } \\
\text { adalah crew. } \\
\text { 1b. Pengguna } \\
\text { adalah admin. }\end{array}$ \\
\hline $\begin{array}{l}\text { postSettingUpdat } \\
\text { e(Request } \\
\text { \$request) }\end{array}$ & $\begin{array}{l}\text { 1. Lakukan validasi input. } \\
\text { 2. Jika pengguna adalah admin } \\
\text { perbarui data admin } \\
\text { berdasarkan parameter request } \\
\text { dan selesai. } \\
\text { 2b. Jika pengguna adalah crew } \\
\text { perbarui data } \text { crew berdasarkan } \\
\text { parameter request. } \\
\text { 3. Jika input picture ada, } \\
\text { perbarui gambar } \text { crew. } \\
\text { 4. Tampilkan halaman } \\
\text { setting dengan pesan berhasil. }\end{array}$ & $\begin{array}{l}\text { 1a. Input } \\
\text { username } \\
\text { kosong. } \\
\text { 1b. Input } \\
\text { konfimasi } \\
\text { password baru } \\
\text { tidak cocok. } \\
\text { 1c. Input } \\
\text { handphone, } \\
\text { address atau } \\
\text { about untuk } \\
\text { crew kosong. } \\
\text { 1d. Input } \\
\text { picture tidak } \\
\text { dalam format } \\
\text { JPEG atau } \\
\text { PNG. } \\
\text { 2a. Pengguna } \\
\text { adalah admin. } \\
\text { 2b. Pengguna } \\
\text { adalah crew. } \\
\text { 3a. Input } \\
\text { picture tidak } \\
\text { ada. } \\
\text { 3b. Input } \\
\text { picture ada. }\end{array}$ \\
\hline
\end{tabular}

Tabel 5. White Box Testing pada Career Controller

\begin{tabular}{|l|l|l|}
\hline Method & Algoritma & Test case \\
\hline index() & $\begin{array}{l}\text { 1. Buat elemen nomor halaman. } \\
\text { 2. Tampilkan halaman } \\
\text { careers beserta data careers dan } \\
\text { data yang didapatkan pada } \\
\text { langkah 1. }\end{array}$ & $\begin{array}{l}\text { 1. Ubah nilai } \\
\text { dari data } \\
\text { careers. }\end{array}$ \\
\hline create() & $\begin{array}{l}\text { 1. Tampilkan halaman } \\
\text { tambah } \\
\text { career. }\end{array}$ & \\
\hline
\end{tabular}




\begin{tabular}{|c|c|c|}
\hline $\begin{array}{l}\text { store(Program } \\
\text { Request \$request) }\end{array}$ & $\begin{array}{l}\text { 1. Lakukan validasi input. } \\
\text { 2. Simpan data career } \\
\text { berdasarkan parameter request. } \\
\text { 3. Simpan gambar ads. } \\
\text { 4. Redirect } \text { ke halaman careers. }\end{array}$ & $\begin{array}{l}\text { 1a. Input } \\
\text { title, } \\
\text { description } \\
\text { atau picture } \\
\text { kosong. } \\
\text { 1b. Input } \\
\text { picture bukan } \\
\text { dalam format } \\
\text { JPEG atau } \\
\text { PNG. } \\
\text { 2. Ubah } \\
\text { nilai } \\
\text { parameter.. }\end{array}$ \\
\hline $\operatorname{edit}(\$ i d)$ & $\begin{array}{l}\text { 1. Dapatkan data } \\
\text { career } \\
\text { berdasarkan parameter } i d \text {. } \\
\text { 2. Tampilkan halaman } \\
\text { ubah career berserta data yang } \\
\text { didapatkan dari langkah } 1 \text {. }\end{array}$ & $\begin{array}{l}\text { 1. Ubah } \\
\text { nilai dari } \\
\text { parameter } i d \text {. }\end{array}$ \\
\hline $\begin{array}{l}\text { update(ProgramR } \\
\text { equest \$request, } \\
\text { \$id) }\end{array}$ & $\begin{array}{l}\text { 1. Lakukan validasi input. } \\
\text { 2. Perbarui data } \\
\text { career berdasarkan parameter } \\
\text { request dan } \text { id. } \\
\text { 3. Jika ada input picture } \\
\text { maka perbarui gambar } \text { career. } \\
\text { 4. Redirect ke halaman ubah } \\
\text { careers dengan pesan berhasil }\end{array}$ & $\begin{array}{l}\text { 1a. Input } \\
\text { title, } \\
\text { description } \\
\text { atau status } \\
\text { kosong. } \\
\text { 1b. Input } \\
\text { picture bukan } \\
\text { dalam format } \\
\text { JPEG atau } \\
\text { PNG. } \\
\text { 2. Ubah } \\
\text { nilai } \\
\text { parameter. } \\
\text { 3a. Tidak } \\
\text { ada input } \\
\text { picture. } \\
\text { 3b. Ada input } \\
\text { picture. }\end{array}$ \\
\hline $\begin{array}{l}\text { updateStatus(Req } \\
\text { uest \$request, \$id) }\end{array}$ & 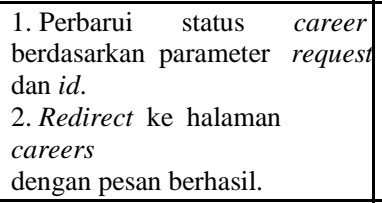 & $\begin{array}{l}\text { 1. Ubah } \\
\text { nilai } \\
\text { parameter. }\end{array}$ \\
\hline destroy(\$id) & $\begin{array}{l}\text { 1. Hapus career berdasarkan } \\
\text { parameter id. }\end{array}$ & $\begin{array}{l}\text { 1. Ubah } \\
\text { nilai } \\
\text { parameter }\end{array}$ \\
\hline
\end{tabular}

\section{User Testing}

User testing merupakan usability evaluation yang dilakukan pada pengguna secara langsung yang bertujuan untuk menemukan masalah yang muncul saat pengguna menjalankan suatu tugas tertentu. User testing dilakukan setelah pengguna mendapatkan pelatihan terlebih dahulu. Parameter yang digunakan untuk mengukur hasil dari user testing yakni difficulty of use yang bersifat subjektif dan jumlah tugas yang gagal yang bersifat objektif. Rentang nilai untuk parameter difficulty of use adalah satu sampai sepuluh.

\section{KESIMPULAN DAN SARAN}

Berdasarkan pokok permasalahan yang telah dikemukakan dan hasil pembahasan desain implementasi website yang diberikan sebagai solusi untuk menyelesaikan permasalahan pada Memora FM Manado dengan menggunakan metodologi Web Modeling Language, maka dapat disimpulkan bahwa telah berhasil dibangun website Memora FM Manado yang memiliki kegunaan antara lain: jangkauan penyiaran program on-air menjadi lebih luas karena bisa didengar melalui website, dapat memberikan informasi program off-air yang akan datang, dapat memberikan music chart terkini versi Memora FM Manado, iklan yang disiarkan melalui siaran radio dapat juga promosikan melalui website, memperkenalkan Memora FM Manado melalui profil perusahaan yang ada dalam website, dan memberitahukan lowongan pekerjaan yang tersedia, dan mempermudah para pendengar radio untuk memperoleh informasi program on-air, off-air terbaru dan program yang sedang open request melalui $e$-mail.

Adapun yang menjadi saran untuk penelitian selanjutnya antara lain: Informasi jadwal program on-air dan off-air pada bagian administrasi dapat digambarkan dalam bentuk chart yang lebih mudah dimengerti dari sebelumnya, bagian audio streaming pada pengunjung dapat menampilkan musik yang sementara diputar, dan dapat ditambahkan fitur untuk chatting ketika ada topik tertentu yang dibahas saat program sementara on-air, serta dapat melakukan polling dan memberikan quiz.

\section{DAFTAR PUSTAKA}

[1] Brambilla, M. Comai, S. Fraternali, P. Matera, M. (2008). Web Engineering: Modeling and Implementing Web Applications. London:Springer-Verlag.

[2] Ceri, S. Fraternali, P. Bongio, A. Brambilla, M. Comai, S. Matera, M. (2003). Designing Data-Intensive Web Applications. San Francisco:Morgan Kaufmann Publishers.

[3] Coronel, C. Morris, S. Rob, P. (2010). Database Systems: Design, Implementation, and Management. (Edisi ke-9). Boston:Cengage Learning.

[4] Elmasri, R. Navathe, S. B. (2011). Fundamentals of Database Systems. (Edisi ke-6). Boston:Addison-Wesley.

[5] Gilmore, W. J. (2010). Beginning PHP and MySQL: From Novice to Professional. New York:Apress.

[6] Lengstorf, J. Hansen, T. B. (2014). PHP for Absolute Beginners. (Edisi ke-2). New York:Apress.

[7] Martin, B. (2015). Laravel 5 Essentials. Birmingham:Packt Publishing Ltd.

[8] McCool, S. (2012). Laravel Starter. Birmingham:Packt Publishing Ltd.

[9] McLeod, Jr. R. Schell, G. P. (2008). Sistem Informasi Manajemen. (Edisi ke-10). Jakarta:Penerbit Salemba Empat.

[10] Netherland, W. Weizenbaum, N. Eppstein, C. Mathis, B. (2013). Sass and Compass in Action. Shelter Island:Manning Publication Co.

[11] SASS. (nd). SASS. Tersedia di http://sass-lang.com/guide [Diakses 8 Okt. 2015].

[12] Wahana Komputer. (2010). Panduan Aplikatif \& Solusi Membuat Aplikasi Client Server Dengan Visual Basic 2008. Yogyakarta:Penerbit ANDI.

[13] Yuhefizar. Mooduto, H. A. Hidayati, R. (2009). Cara Mudah Membangun Website Interaktif Menggunakan Content Management System Joomla Edisi Revisi. Jakarta:PT Elex Media Komputindo. 